\title{
Physical Environments as the Determinants of Passenger Delight at Airport. A SEM Approach
}

\author{
Mazlina Mahdzar, Nur Aida Amani Baharuddin
}

To Link this Article: http://dx.doi.org/10.6007/IJARBSS/v11-i16/11204

DOI:10.6007/IJARBSS/v11-i16/11204

Received: 02 July 2021, Revised: 22 July 2021, Accepted: 21 August 2021

Published Online: 09 September 2021

In-Text Citation: (Mahdzar \& Baharuddin, 2021)

To Cite this Article: Mahdzar, M., \& Baharuddin, N. A. A. (2021). Physical Environments as the Determinants of Passenger Delight at Airport. A SEM Approach. International Journal of Academic Research in Business and Social Sciences, 11(16), 1-9.

\section{Copyright: (C) 2021 The Author(s)}

Published by Human Resource Management Academic Research Society (www.hrmars.com)

This article is published under the Creative Commons Attribution (CC BY 4.0) license. Anyone may reproduce, distribute, translate and create derivative works of this article (for both commercial and non-commercial purposes), subject to full attribution to the original publication and authors. The full terms of this license may be seen at: http://creativecommons.org/licences/by/4.0/legalcode

Special Issue Title: Contemporary Issues in Tourism and Hospitality industry, 2021, Pg. 1 - 9 


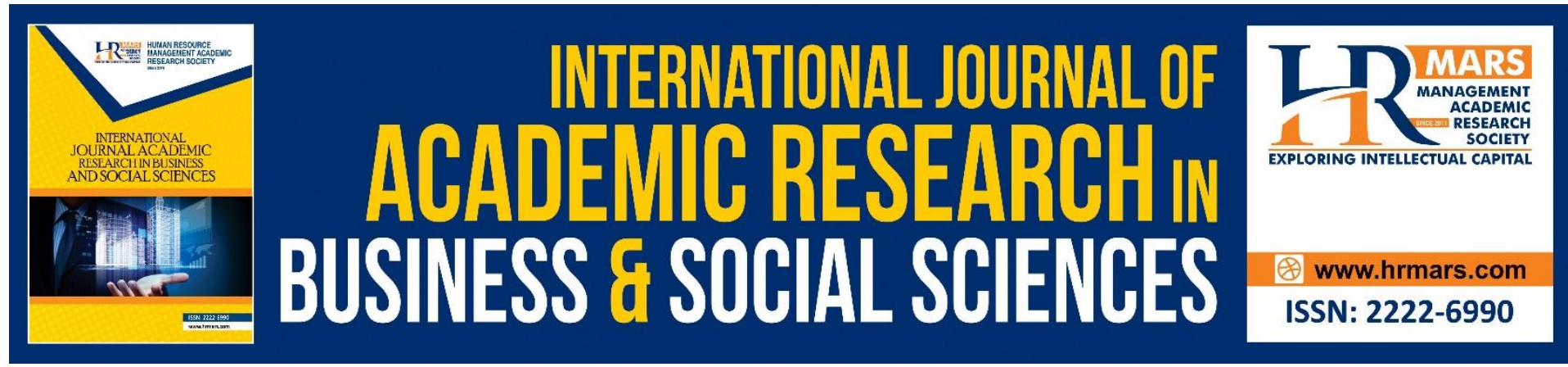

\title{
Physical Environments as the Determinants of Passenger Delight at Airport. A SEM Approach
}

\author{
Mazlina Mahdzar, Nur Aida Amani Baharuddin \\ Faculty of Hotel and Tourism Management, Universiti Teknologi MARA, Cawangan Selangor, \\ Malaysia \\ Email: nina@uitm.edu.my
}

\begin{abstract}
In tourism development, the impact of demand for air transport by travellers affects new forms of tourism and new destinations. The airport is a consistent growth segment in the industry of travel and transportation. This paper aims to examine the relationship of airport physical environment elements and passengers' delight. Studies on the physical environment impact on pasengers' delight are limited, especially in the context of international airports. Data were collected at Kota Kinabalu International Airport (KKIA), and 400 sets of questionnaires were distributed, out of which, 385 were completed and used for analysis. The data were analyzed using SPSS and AMOS statistical software. Throughout the study, it has been identified that airport's ambiance \& aesthetics and cleanliness elements of the physical environment in an international airport influences passengers' delight. The implications of physical environment elements were discussed in detail. Overall, the findings of this study contributed to the broader literature, and it can be further replicated in other fields of study for future research.
\end{abstract}

Keywords: Physical Environment, Passengers' Delight, International Airports, SEM-AMOS

\section{Introduction}

Abundant travellers are now traveling through the air, and the aviation industry has contributed to international tourism's booming. Tourists are seen taking long-haul and short haul trips for movements within countries using air transport to travel from and to their destinations (Bieger \& Wittmer, 2006; Forsyth, 2006; Papatheodorou \& Lei, 2006). To stay alongside with the increasing number of passengers and visitors to international airports, airports are determined to provide different prospects and services to passengers and business operators alike. Bogicevic (2014); Bilgihan \& Bujisic (2013) reasoned that the increase in travel cosiness and technology has caused passengers' expectancy for an airport experience. Passengers today are vulnerable to various types of services that guide them to differentiate the performance of preferred carriers (Bogicevic, 2014). Airport functions as temporary point for passengers and each of them will have a diverse set of requirements and requirements when they use various facilities at the airport (Jin-Woo \& Se-Yeon, 2011). The airport's infrastructure is the initial point of contact for travellers before starting their holiday point to a destination. Thus, airport amenities provide them with the main picture about the 
value of time they expect (Martín-Cejas, 2006). In this context, airports focus on developing strategies to ensure delightful experiences among visitors and its physical environments that are becoming more important attention as part of that purpose (Ariffin \& Yahaya, 2013; Moon et al., 2015).

Chen \& Chang (2005), Bogicevic et al. (2013) and Martín-Cejas (2006) in their study revealed that in the nature of air transport, air travel is categorized into two parts: in-flight services and ground services. The ground services relate to the study of airport experiences, including when travellers are administered by airports that use numerous services such as information collection counters, booking and ticket purchases, check-in. Accordingly, functionality, layout accessibility, facility aesthetics and cleanliness are the four main elements of the physical environment (Ali, 2016; Moon et al., 2015). According to Bitner (1992), the physical environment is focused on the airport ground services and its operators and vendors. This includes restaurants, shop and retail outlets, banks, professional services such as money changers and more as it creates an apparent image and affects passenger behaviour. Moreover, physical environment has a legal effect on the customer's emotions, such as arousal and enjoyment (Moon et al., 2015; Han \& Ryu, 2009).

The physical environment in service industries is a critical determinant of customer emotion and positive responses (Ryu et al., 2012), but few researches conducted to examined how the physical environment of international airports can develop customer delight and satisfaction (Jeon \& Kim, 2012; Moon et al., 2015). Thus, this study was conducted to fill this gap by revealing how airport physical environments influence passenger delight in one of an international airport in Malaysia. Kota Kinabalu International Airport (KKIA) is one of the busiest international airports in Malaysia after the Kuala Lumpur International Airport (KLIA). The number of passengers at the KKIA in 2017 was 8,006,446 travellers and has increased by 743,107 travellers since 2016 (MAHB, 2018). Moreover, 8,622,488 are the number of passenger movements recorded in 2018 (MAHB, 2019). Therefore, this study investigates the relationship between airport physical environment elements and passengers' delight at Kota Kinabalu International Airport.

\section{Literature Review}

Scholars have focused on a number of dimensions of the physical environment, revealing some disagreement over physical environment dimensions for all service organizations (Jeon \& Kim, 2012). The first dimension, layout accessibility refers to how the spatial relations between these elements and also the layout of furniture and equipment, service areas, and routes (e.g. Bittner, 1992; Wakefield \& Blodgett, 1996; Ryu \& Jang, 2007; Moon et al., 2015; Ali et al., 2016; Ryu \& Han, 2011). Next, facility ambience \& aesthetics dimensions, according to Ryu \& Han (2011), refers aesthetics of the facility to the architectural and interior design, décor that increases the attractiveness of the environment. The ambience elements are characterized as intangible environmental backgrounds that non-visual sensors tend to be affected, and customers may have an unconscious effect (Ryu \& Jang, 2007; Ryu \& Han, 2011). Functionality dimension refers to as physical object capabilities (e.g., physical machinery, equipment, furniture, and facilities) to help customers experience a pleasant experience by performing their functions effectively (Moon et al., 2015; Bitner, 1992; Moon et al., 2015; Ali et al., 2016). Lastly, the cleanliness dimension is another crucial part of the service. For example, as Ali et al (2015) emphasized, the toilet's hygiene, food service area, and pedestrian route and exit at the airports positively impact customer excitement. Baker (1987) discussed the way these physical environment dimensions influences customers' judgments of services. 
Bitner (1992) further suggested that the physical environment found to be an important part of consumer evaluation of satisfaction of services. Furthermore, Ryu (2012) suggested that satisfaction with the physical environment leads to more favourable customers responses such as perception of comfort and increased positive word of mouth intentions.

Passenger delight is defined as a response that a customer can when the service or product provides unexpected value or unexpected satisfaction as the customer uses and also experiences it (Magnini, 2011). Schneider and Bowen (1999) indicated that surpassing customer expectations create customer delight. In this context, delight is often connected with emotional reaction like joy, excitement, and encouragement as elements of surprise amplifying this emotion. For this reason, delightful experience usually has a stronger memory effect and, thus, more effective than a satisfying experience (Magnini et al., 2011) and can determine the overall assessment of positive experience (Torres et al., 2014).

International airports basically are meant to provide international flights to tourists (Jeon \& Kim, 2012). However, airports are now transformed into mini-cities equipped with different type of facilities and activities such as basic installations for aircraft, support buildings, security areas, retail malls, fitness centres, business centres, hotels, and restaurants (Yeo, 2010). These service environments of an airport must be managed well for excellent international airport services. Based on the literature review, this study supports the conceptualization of passenger delight as positive emotions elicited by a stimulus such as physical environment of an international airport (Finn, 2005; Schümmer, 2007). The four elements of the physical environment of the airport, layout accessibility, facility aesthetics, functionality, and cleanliness are essential elements that affect pleasure (Ali et al., 2016; Wakefield \& Blodgett, 1996; Lin \& Liang, 2011; Moon et al., 2015).

\section{Methods}

To ensure the validity, all the measurement items were taken from previous studies; however, minor modifications to the statements were made to make them adequate for the present study. 'Layout accessibility', 'Facility ambiance \& Aesthetics', 'Functionality', and 'Cleanliness' were all measured using 6 items each whereas 'passengers delight' was operationalized using 5-items adopted from Ariffin \& Yahaya (2013) and Ali et al. (2016). All the items were measured using a five-point Likert scale starting from 1 (strongly disagree) to 5 (strongly agree). The researchers used a self-administered survey to collect data from customers at Kota Kinabalu International Airport, Malaysia. Based on convenience sampling, 400 questionnaires were distributed, 385 were returned and were deemed fit for further procedures.

Data analysis for this study applied SPSS version 21.0 to process the descriptive statistics and reliability analysis on the collected data and assess the demographic profile of the sample and the internal consistency of the constructs. Anderson and Gerbing (1988) suggested this study assessed the properties of measurement scales for convergent validity and discriminant validity and constructed composite reliability by confirmatory factor analysis (CFA). The study then applied Structural Equation Modelling (SEM-AMOS) to test the hypotheses.

\section{Result}

The measurement model was tested for the convergent validity of this study. This was assessed through factor loadings, composite reliability (CR) and average variance extracted (AVE) (Hair et al., 2013). In the layout accessibility construct, one item was removed due to low factor loading. Two items from Facility Ambience \& Aesthetics construct, and three items from Functionality constructs were removed. Table 1 shows the remaining item loadings that 
exceeded the recommended value of 0.6. Composite reliability values, which depict the degree to which the construct indicators indicate the latent construct, exceeded the recommended value of 0.7 (Hair et al., 2013) while average variance extracted, which reflects the overall amount of variance in the indicators accounted for by the latent construct, exceeded the recommended value of 0.5 (Hair et al., 2013). Discriminant validity, which is achieved when the measurement models are free from unnecessary items (Awang, 2012), indicated adequate discriminant validity and convergent validity. Consequently, this measurement model was used for further analyses and hypotheses testing using the structural model.

Table 1 Validity and Reliability for Construct.

\begin{tabular}{|c|c|c|c|c|}
\hline Constructs & Items & $\begin{array}{l}\text { Factor } \\
\text { Loadings }\end{array}$ & AVE & CR \\
\hline \multirow[t]{6}{*}{ Layout Acessibility } & & & 0.513 & 0.840 \\
\hline & $\begin{array}{l}\text { The airports signs clearly directed } \\
\text { me to services such as parking, car } \\
\text { rentals, terminals, ATM, etc. }\end{array}$ & 0.668 & & \\
\hline & $\begin{array}{l}\text { Baggage trolleys were available and } \\
\text { conveniently located }\end{array}$ & 0.659 & & \\
\hline & $\begin{array}{l}\text { The layout was properly designed } \\
\text { to cater passengers with specific } \\
\text { needs, i.e., disabled, smokers, } \\
\text { pregnant women, etc., }\end{array}$ & 0.770 & & \\
\hline & $\begin{array}{l}\text { Well-known retail and dining } \\
\text { options were available and } \\
\text { conveniently located. }\end{array}$ & 0.715 & & \\
\hline & $\begin{array}{l}\text { The layout was properly managed } \\
\text { to avoid passenger crowding and } \\
\text { easy movement. }\end{array}$ & 0.763 & & \\
\hline \multirow{6}{*}{$\begin{array}{l}\text { Facility Ambiance } \\
\text { \& Aesthetics }\end{array}$} & & & 0.623 & 0.868 \\
\hline & & & & \\
\hline & $\begin{array}{l}\text { The colour schemes within the } \\
\text { airport were attractive. }\end{array}$ & 0.834 & & \\
\hline & $\begin{array}{l}\text { The architecture and decoration of } \\
\text { the airport were appealing }\end{array}$ & 0.850 & & \\
\hline & $\begin{array}{l}\text { The brightness within the airport } \\
\text { was welcoming. }\end{array}$ & 0.769 & & \\
\hline & $\begin{array}{l}\text { The aroma within the airport was } \\
\text { pleasant }\end{array}$ & 0.694 & & \\
\hline \multirow[t]{3}{*}{ Functionality } & & & 0.593 & 0.813 \\
\hline & $\begin{array}{l}\text { This airport provided comfortable } \\
\text { and spacious seating in the waiting } \\
\text { areas }\end{array}$ & 0.749 & & \\
\hline & $\begin{array}{l}\text { The signs and electronic displays } \\
\text { provide information accurately and } \\
\text { clearly }\end{array}$ & 0.817 & & \\
\hline
\end{tabular}




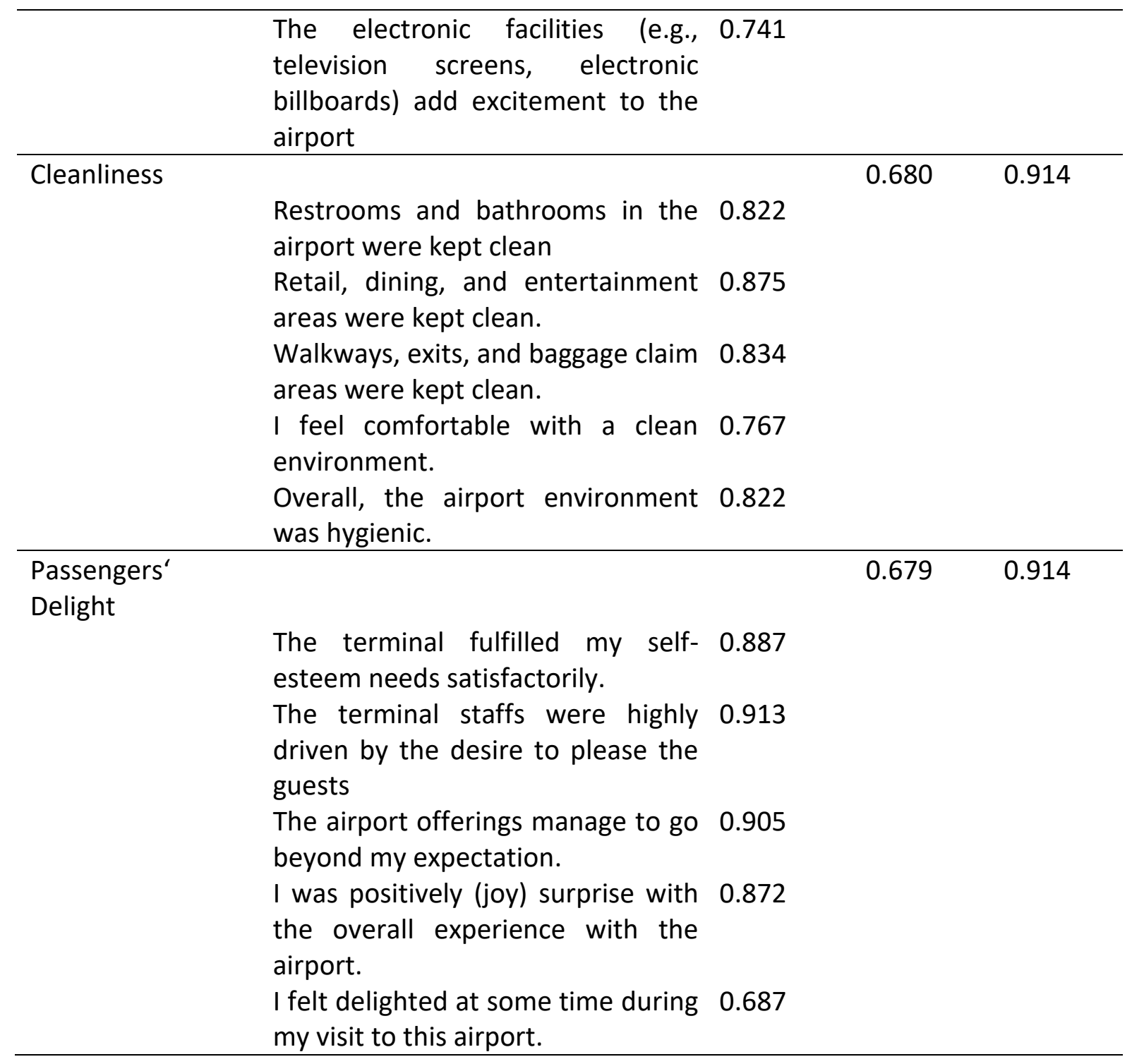

To estimate the parameters, a structural model of airline physical environment and passengers delight was constructed. The aim of constructing a structural model was to test whether the four constructs of airline physical environment significantly influence passengers' delight. The results show that $\chi 2$ is significant $(\chi 2 / d f=2.828, \rho=0.000 ; I F I=0.928, C F I=0.928$, $\mathrm{TLI}=0.917$; RMSEA $=0.069$ ). The model had an RMSEA value of 0.069 , which is also within the required range and is considered satisfactory. The structural results of the proposed model and the effect of predictors on passengers' delight are depicted in table 2. 
Table 2: Results of Structural Model

\begin{tabular}{llll}
\hline Hypothesised relationship & $\begin{array}{l}\text { Standardised } \\
\text { Coefficient }\end{array}$ & $\mathbf{p}$ & Decision \\
\hline $\begin{array}{l}\text { Layout Accessibility } \rightarrow \text { Passengers' Delight } \\
\text { Facility Ambiance \& Aesthetics } \rightarrow 0.069\end{array}$ & 0.409 & 0.000 & Sot Significant \\
$\begin{array}{l}\text { Passengers' Delight } \\
\text { Functionality } \rightarrow \text { Passengers' Delight }\end{array}$ & 0.147 & 0.096 & Not Significant \\
Cleanliness $\rightarrow$ Passengers' Delight & 0.282 & 0.000 & Significant \\
\hline
\end{tabular}

The results indicate that Facility Ambiance \& Aesthetics ( $\beta=0.409 ; p=0.00)$ and Cleanliness ( $\beta=0.282 ; p=0.000$ ) exert a significant effect on passengers' delight. Meanwhile, Layout Accessibility and Functionality do not affect passenger delight where $p$-value $>0.05$.

\section{Discussion, Conclusion and Implications of Research}

This research entailed an empirical study to investigate the effect of the physical environment on passengers' delight in an international airport. This study highlighted that the airport's ambiance $\&$ aesthetics, and cleanliness of its physical environment in an international airport influences passengers' delight.

The findings of this study provide some implications for airport managers and service operators to understand customers' needs concerning the international airports' physical environment. The study found that facility ambience and aesthetics is the most important element affecting passengers' delight. Such findings align with Ryu and Jang (2007) and Ryu and Han (2011), who note that ambience elements affect the five senses and influence state consumer sentiment, mood, or emotion. Moreover, emotions can be predicted by the facility's aesthetics (Ryu \& Jang, 2007; Ali et al., 2016; \& Ryu \& Han, 2011). Therefore, the airport must ensure a cosy atmosphere and exciting architectural and interior design being offered to enhance passengers' delight with the airport further. Besides, the result of this study also found that cleanliness is another important element for passengers' delight. Therefore, airport service operators need to maintain and improve the aspects of cleanliness as passengers spend most of their time at the airport waiting for baggage check-in, security checks, and waiting before boarding.

To stay competitive, airports must also develop an attractive and convincing physical environment to delight their visitors. For example, adding other physical environments of the airport such as embedding state or country identity such as local art, local food, local merchandise, and souvenirs may act as a pull factor that may also enhance passengers' delight and develop revisit intentions. These would help create the atmosphere and feeling of being in the state and country while the tourists are still at the airport terminal. Similar to any research study, this study also had some limitations. Convenience sampling was employed to select the sample from only one international airport. Thus, results may not be generalized to a wider population. Additional studies with other airports and testing perceptions on their behavioural intentions should be conducted to increase the opportunity to make comparisons and gain further insights.

\section{References}

Ali, F., Kim, W. G., \& Ryu, K. (2016). The effect of physical environment on passenger delight and satisfaction: Moderating effect of national identity. Tourism Management, 57, 213224. 
Anderson, J. \& Gerbing, D. (1988). Structural modeling in practice: a review and recommended two-step approach. Psychological Bulletin. 103(3), 411-23.

Ariffin, A. A., \& Yahaya, M. F. (2013). The relationship between airport image, national identity and passengers delight: A case study of the Malaysian low cost carrier terminal (LCCT). Journal of Air Transport Management, 31, 33-36.

Awang, Z. (2012). Structural Equation Modeling Using AMOS Graphic. Penerbit Universiti Teknologi Mara.

Bieger, T., \& Wittmer, A. (2006). Air transport and tourism-Perspectives and challenges for destinations, airlines and governments. Journal of air transport management, 12(1), 4046.

Bitner, M. J. (1992). Servicescapes: The impact of physical surroundings on customers and employees. Journal of Marketing, 56(2), 57-71.

Bogicevic, V. (2014). The effect of airport servicescape features on traveler anxiety and enjoyment. (Graduate Theses and Dissertations).

Chen, F. Y., \& Chang, Y. H. (2005). Examining airline service quality from a process perspective. Journal of Air Transport Management, 11(2), 79-87.

Finn, A. (2005). Reassessing the foundations of customer delight. Journal of Service Research, 8(2), 103-116.

Forsyth, P. (2006). Martin Kunz memorial lecture. Tourism benefits and aviation policy. Journal of Air Transport Management, 12(1), 3-13.

Hair, J. F., Hult, G. T. M., Ringle, C., \& Sarstedt, M. (2013). A primer on partial least squares structural equation modelling (PLS-SEM). Sage Publications.

Jeon, S., \& Kim, M. S. (2012). The effect of the servicescape on customers' behavioral intentions in an international airport service environment. Service Business, 6(3), 279295.

Jin-Woo, P., \& Se-Yeon, J. (2011). Transfer passengers' perceptions of airport service quality: A case study of Incheon international airport. International Business Research, 4(3), 75.

Lin, J., and Liang, H. (2011). The influence of service environments on customer emotion and service outcomes. Managing Service Quality, 21(4), $350-372$.

Magnini, V. P., Crotts, J. C., \& Zehrer, A. (2011). Understanding customer delight: An application of travel blog analysis. Journal of Travel Research, 50(5), 535-545.

MAHB. (2018). Annual Report 2017. Malaysia Airports. https://www.malaysiaairports.com.my/sites/corporate/files/2018-09/ar2017.pdf

MAHB. (2019). Airport Statistic 2018. http://annualreport2018.malaysiaairports.com.my/downloads/airportstatistics2018.p df

Martín-Cejas, R. R. (2006). Tourism service quality begins at the airport. Tourism Management, 27(5), 874-877.

Moon, H., Yoon, H. J., \& Han, H. (2015). Role of airport physical environments in the satisfaction generation process: Mediating the impact of traveller emotion. Asia Pacific Journal of Tourism Research, 21(2), 193-211.

Papatheodorou, A., \& Lei, Z. (2006). Leisure travel in Europe and airline business models: A study of regional airports in Great Britain. Journal of Air Transport Management, 12(1), 47-52.

Ryu, K., \& Han, H. (2011). New or repeat customers: how does physical environment influence their restaurant experience? International Journal of Hospitality Management, 30(3), 599-611. 
Ryu, K., \& Jang, S. S. (2007). The effect of environmental perceptions on behavioral intentions through emotions: The case of upscale restaurants. Journal of Hospitality \& Tourism Research, 31(1), 56-72.

Ryu, K., Lee, H. R., \& Gon Kim, W. (2012). The influence of the quality of the physical environment, food, and service on restaurant image, customer perceived value, customer satisfaction, and behavioral intentions. International Journal of Contemporary Hospitality Management, 24(2), 200-223.

Schneider, B., \& Bowen, D. E. (1999). Understanding customer delight and outrage. Sloan Management Review, 41(1), 35-45.

Schümmer, B. (2007). Cognitive and affective antecedents of and behavioral intentions connected to delight, satisfaction, dissatisfaction, and outrage in the Dutch academic education market. (Doctoral dissertation) University Maastricht.

Torres, E. N., Fu, X., \& Lehto, X. (2014). Examining key drivers of customer delight in a hotel experience: A cross-cultural perspective. International Journal of Hospitality Management, 36, 255-262.

Wakefield, L. K., \& Blodgett, J. G. (1994). The importance of servicescape in leisure service settings. Journal of Service Marketing. 8(3), 66-76.

Yeo, S. H. (2010). A study on the impact of airport service quality on satisfaction: Focusing on Daegu international airport. Academy of Korean Hospitality Tourism. 12(2), 177-189. 